this expected decrease in life-span will be due to leukæmia, which is known to affect over-exposed individuals with more than average frequency. The question whether diagnostic $\mathrm{X}$-radiation during pregnancy increases the incidence of leukæmia in the children cannot be decided on the available evidence. Neither can it be decided whether there is a lower threshold to the production of tumours and leukæmia by irradiation, but the sub-committee dealing with hæmatological effects thinks it prudent to assume that for leukæmia no threshold exists. Mammalian embryos are readily affected by low doses of ionizing radiation. One of the most sensitive known indicators of chronic biological damage is the gradual reduction in number, motility and viability of sperm, resulting from small chronic radiation over-exposure. In dogs, effects on sperm have been observed at chronic doserates of only ten times the maximum permissible value for human occupational exposure.

\section{MODERNIZATION OF THE STOCKHOLM CYCLOTRON}

$I^{\mathrm{N}}$ 'two papers published during 1952, H. Atterling and $G$. Lindström described the initial performance of the fixed frequency $225-\mathrm{cm}$. cyclotron at the Nobel Institute of Physics, Stockholm (Arkiv for Fysik, 4, $559 ; 1952$, and Nature, 169,$432 ; 1952)$. A more detailed description of the machine, which has operated reliably and stably for several years producing internal beams of protons, deuterons, alphaparticles and heavy ions (carbon, nitrogen, oxygen and neon ions), is given in two recent articles in Arkiv for Fysik $(15,483$ and $531 ; 1959)$. The oscillator-frequency used recently is $8.1 \mathrm{Mc} . / \mathrm{s}$. and with this frequency the machine accelerates ions to a nominal energy of about $11 \mathrm{MeV}$. per nucleon at a radius of $90 \mathrm{~cm}$. Internal beam currents of approximately $300 \mu \mathrm{mp}$. of $22-\mathrm{MeV}$. deuterons are obtained.

In March 1958, the cyclotron was shut down and taken to pieces for remodelling. Previously it had been run exclusively with internal beams, but when the dees were designed provision was made for the subsequent mounting of an internal d.c.-deflector in one of the dees and during the reassembly of the dees the deflector is being installed. mentioned.
Considerable space is devoted to recommendations for future research, especially in the field of genetics. The need for basic research is stressed, and the relevance of mutation research on all forms of life, including bacteria and viruses, is pointed out. On the other hand, attention is directed to problems that arise in human populations and have no counterpart in animal societies. Thus: "human society depends upon a diversity of performance among its members and on very high mental qualities among a few of them. A human civilization might collapse by becoming qualitatively inadequate, even though reproductive selection of certain kinds were acting at high intensity and the number of individuals in the population remained at a level that was previously optimal". These sentences have an obvious relevance to the questions discussed in the leading article "Evolution of Mankind" in Nature of February 13. C. Aumrbach

The machine is housed in an underground hall, resting directly on rock and surrounded on all sides by rock, clay and earth. On the top it is shielded by a water pond two metres deep. The control room is in a three-storey building above ground, and the connexion between the building and the cyclotron hall is via a stairway or a lift to the bottom of a shaft from which a corridor leads to the hall. A removable $150-\mathrm{cm}$. concrete thick wall partly closes the corridor, leaving an opening $140 \mathrm{~cm}$. broad which can be closed by a concrete door weighing 35 tons. The first article contains full details together with drawings and photographs of the building; the magnet ; the radiofrequency tank and dee systems; and the ionsource of the cyclotron. In the second article the techniques used in the work on heavy-ion acceleration in the cyclotron together with some results of the investigation of the energy-distribution for ${ }^{12} \mathrm{C}^{1+}$ ions are outlined. It is shown that the distribution contains a low-energy component in addition to the higher-energy peak of the ions. Other applications of the accelerated heavy-ions, in particular for the production of transuranium elements, are briefly

\title{
DAILY FOOD CONSUMPTION BY SOUTH AFRICAN UNIVERSITY STUDENTS
}

$I^{\mathrm{T}}$ has been the practice of the Department of Physiology of the University of the Witwatersrand to request students, as part of their physiological training, to keep a daily record of their food consumption over a defined period of time. The records from one year's class form the basis of a preliminary report by Sonia E. Walker ; but it is hoped that data accumulating over several years will afterwards be analysed, and will give some indication of the diet. ary trends in this student section of the community (South African J. Med. Sci., 24, December, 1959).

The food consumption-levels of the students investigated are similar to those reported from other parts of the world. In a survey of dietary levels of households in the United States, the average consumption per person per day was found to be $2,760-3,260$ calories, 87-115 gm. protein and 133-161 gm. fat. The share of total calories derived from carbohydrate was 43 per cent, from protein 13 per cent, and, from fat, 44 per cent. A more recent report based on the estimation of apparent civilian consumption per capita per day in the United States gives mean daily intakes of 3,160 cal., $96 \mathrm{gm}$. protein, $378 \mathrm{gm}$. carbohydrate and $144 \mathrm{gm}$. fat. In the United Kingdom a similar estimation of food consumption per head of civilian. population per day gave 2,890 cal., $380 \mathrm{gm}$. carbohydrate, $112 \mathrm{gm}$. fat, and $90 \mathrm{gm}$. protein. 
The mean daily fat intake of the male group of South African students was $110 \mathrm{gm}$. This is considerably less than the average American intake, but similar to the daily intake in Britain. The mean protein consurnption of the male medical students is $102 \mathrm{gm}$. per day, which is higher than that found in the United States or Britain.

For practical purposes, the majority of the medical students could probably be classed as sedentary workers, as a large part of their day is spent in sitting in lectures and in dissecting rooms, or in doing laboratory work. Recommended daily allowances for young males doing sedentary work range from 2,400 cal. and $70 \mathrm{gm}$. protein according to American standards to 2,250 cal. and $66 \mathrm{gm}$. protein according to British standards.

The present study showed a marked sex difference in food intakes between the male and female students. This is in agreement with observations made on college men and women in the United States, where the men were found to consume more meat, milk and cereals than the women students.

The calorie intake of the Johannesburg women students was slightly less than that found in a group of American students of comparable age, body-weight and height.

\title{
DISTRIBUTION OF ATMOSPHERIC OZONE; A PRELIMINARY ANALYSIS OF SOME INTERNATIONAL GEOPHYSICAL YEAR OBSERVATIONS
}

\section{By J. MACDOWALL}

\begin{abstract}
Royal Society International Geophysical Year Expedition, c/o The Royal Society, Burlington House, London, W.I
\end{abstract}
$\mathrm{T}$ HE three years of total atmospheric ozone observations at Halley Bay $\left(75^{\circ} 31^{\prime}\right.$ S., $26^{\circ} 37^{\prime}$ W. $)$ do not fit into the world-wide picture of the ozone distribution first measured by Dobson ${ }^{1}$ from $68^{\circ} \mathrm{N}$. to $44^{\circ} \mathrm{S}$. Maximum amounts of ozone are not observed until the equivalent of 2-3 months after the seasonal maximum in high northern latitudes, and the highest values observed in the southern hemisphere are lower than in the north.

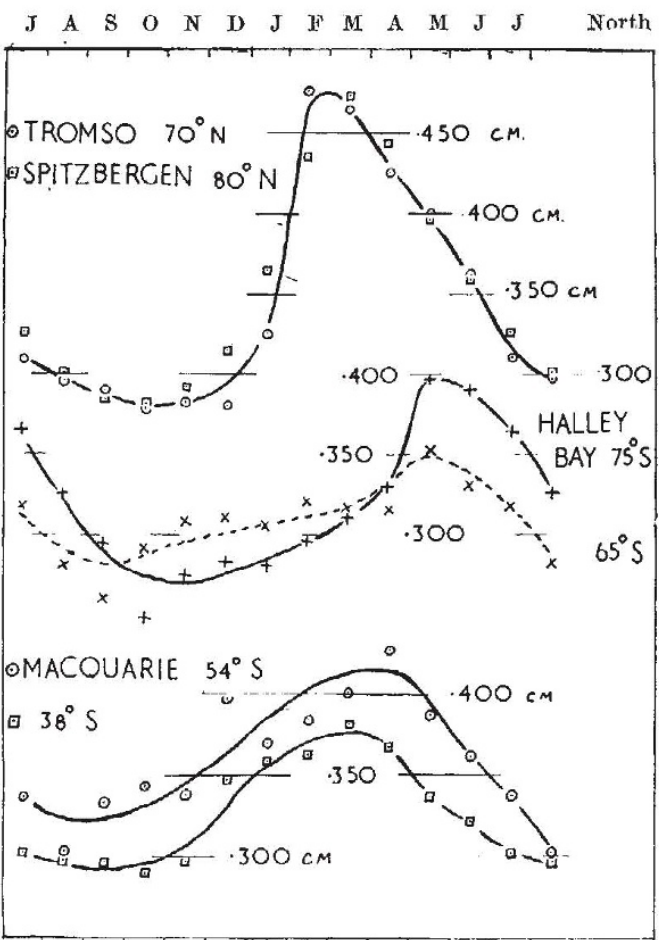

$\begin{array}{lllllllllllllll}J & F & \text { I } & A & \text { M } & J & J & A & S & O & N & D & J & \text { South }\end{array}$

Fig. 1. Shows that the type of seasonal variation of total ozone at Halley Bay is also discernible at Argentine Islands $\left(65^{\circ} \mathrm{S}\right.$.) and the seasonal variation at both stations differs greatly from the variation found at high-latitude northern stations
Fig. 1 shows that the type of seasonal variation at Halley Bay is also present, but much less definite, ten degrces to the north at Argentine Islands; the seasonal variation of ozone at both stations differs greatly from the variation found at high-latitude northern stations. International Geophysical Year observations of total ozone at Macquarie Island, Melbourne, and Brisbane show a more 'normal' seasonal variation.

The International Geophysical Year observations from twelve northern and five southern stations are used in Fig. 2 to illustrate the marked difference

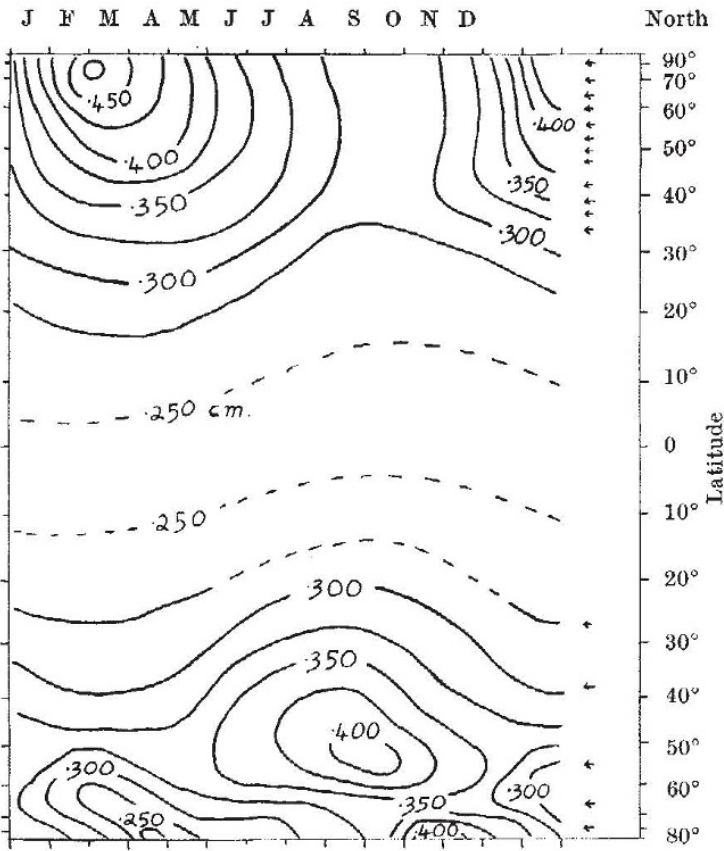

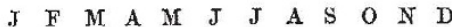

South

Fig. 2. Smoothed monthly mean results of ozone measurements from seventeen stations fllustrating the marked difference between the hemispheres in the seasonal variation of the total quantity of
atmospheric ozone 